\title{
HUBUNGAN MOTIVASI BERPRESTASI DENGAN HASIL BELAJAR MAHASISWA JALUR UMUM PROGRAM STUDI D3 KEBIDANAN STIKes DHARMA HUSADA BANDUNG
}

\author{
Endang Astiriyani \\ Jurusan Kebidanan POLTEKKES Kemenkes Tasikmalaya \\ email : endangasti@gmail.com
}

\begin{abstract}
Objective : To find out the correlation between achievement motivation and student's study achievement at D3 midwifery Spesific Program of STIKes Dharma Husada Bandung.

Method : This study used analytical descriptive method with cross sectional approach. Data were gathered by using questionnaires given to the $2^{\text {nd }}$ semester students. While the student's study achievement were gained through documentation study of their KHS, Study Achievement Card.

Result : The study shows the high motivation level $93(71 \%)$, midle $38(29 \%)$, low and very low are $0(0 \%)$. Study achievement excellent with reward $20(15,3 \%)$, very satisfaction 85 $(64,9 \%)$, satisfaction $25(19,1 \%)$, and need improvement $1(0,8 \%)$.
\end{abstract}

Keywords : Achievement Motivation, Study Achievement.

\section{PENDAHULUAN}

Hasil dari proses belajar tercermin dari prestasi belajar yang dimanifestasikan dalam wujud : 1.) Penambahan materi pengetahuan, 2.) Penguasaan pola perilaku kognitif, perilaku afektif, perilaku psikomotor, 3.) Perubahan dalam sifat-sifat kepribadian baik yang tangible (dapat diamati dalam wujud perilaku) maupun yang intangible (tidak dapat diamati dalam wujud perilaku) (Makmun, 2006).

Cara untuk mengetahui sampai seberapa jauh perubahan yang terjadi, maka dosen seharusnya mengadakan penilaian terhadap performance mahasiswa. Sebagai kriteria atau tolak ukur dalam penilaian tersebut adalah "Seberapa jauh tujuan pembelajaran yang ditetapkan dapat tercapai" (Makmun, 2006).

Intelegensi bukan merupakan satusatunya faktor yang menentukan keberhasilan mahasiswa, tetapi ada faktor-faktor lain yang memengaruhi, salah satunya adalah motivasi khususnya motivasi berprestasi, besar kecilnya pengaruh tersebut tergantung pada intensitasnya. Jika semakin besar harapan untuk berprestasi dan semakin tinggi nilai prestasi tersebut, maka akan besar motivasi seseorang untuk mencapai prestasi (Djalali, 2008).

Proses belajar mengajar sangat memerlukan motivasi, terutama motivasi berprestasi, karena motivasi berprestasi akan senantiasa menentukan intensitas usaha belajar para mahasiswa, sehingga hasil belajar akan menjadi optimal (Sardiman, 2008).

Peran motivasi dalam proses belajar mengajar adalah sebagai berikut : 1.) Mendorong manusia untuk berbuat, motivasi menjadi penggerak dari setiap kegiatan yang akan dikerjakan, 2.) Menentukan arah perbuatan dan kegiatan yang harus dikerjakan sesuai dengan rumusan tujuan, 3.) Menyeleksi perbuatan atau menentukan perbuatan-perbuatan yang harus dikerjakan guna mencapai tujuan (Sardiman, 2008).

STIKes Dharma Husada Bandung memiliki lima Program Studi yakni D3 Kebidanan, D3 Keperawatan, D3 Refraksi Optik, S1 Keperawatan dan S1 Kesehatan Masyarakat. Sesuai dengan tujuan Program Studi Kebidanan STIKes Dharma Husada Bandung "Menghasilkan lulusan yang memiliki kemampuan akademik yang tinggi" (STIKes Dharma Husada, 2008).

Kemampuan akademik mahasiswa ditunjukan dengan nilai Indeks Prestasi 
Akademik (IPK), namun masih ada mahasiswa Program Studi D3 Kebidanan STIKes Dharma Husada Bandung yang memiliki IPK dengan kategori kurang memuaskan (IPK semester <2,00) sebanyak $3,29 \%$, dan dengan kategori memuaskan (IPK semester 2,00-2,75) sebanyak 19,34\% (STIKes Dharma Husada, 2008). Nilai akademik yang rendah dapat mengakibatkan kelulusan yang tidak tepat waktu dan berpengaruh negatif terhadap kecepatan seseorang dalam memperoleh perkejaan yang sesuai dengan bidangnya (Kusumaningsih, 2009).

Berdasarkan hasil studi pendahuluan ternyata rasa sosialisasi mahasiswa STIKes Dharma Husada Bandung masih kurang, hal ini ditunjukan dengan : mahasiswa tidak mengenal akrab mahasiswa lain yang berbeda kelas. Hal ini menunjukan keinginan mahasiswa untuk berhubungan dengan orang lain masih kurang.

Motivasi berprestasi adalah kondisi fisiologis dan psikologis (kebutuhan untuk berprestasi) yang terdapat di dalam diri siswa yang mendorongnya untuk melakukan aktivitas tertentu guna mencapai suatu tujuan tertentu (berprestasi setinggi mungkin) (Djalali, 2008).

Menurut Ausubel motivasi berprestasi terdiri atas tiga komponen, yaitu (Djalali, 2008) :

1. Dorongan Kognitif

Adalah keinginan siswa untuk mempunyai kompetensi dalam subyek yang ditekuninya serta keinginan untuk menyelesaikan tugas yang dihadapinya dengan hasil yang sebaik-baiknya.

2. Harga Diri Akademik (Academic selfesteem)

Adalah keinginan siswa untuk meningkatkan status dan harga dirinya yang berkaitan dengan kehidupan akademik individu.

3. Komponen Afiliasi

Adalah keinginan siswa untuk selalu

berafiliasi dengan siswa lainnya.

Hasil belajar mahasiswa adalah perubahan kemampuan kognitif, afektif dan psikomotor, yang diperoleh mahasiswa dari proses pembelajaran (Sudjana, 2005).

Menurut Atkinson motivasi seseorang ditentukan oleh dua faktor, yaitu (Djalali, 2008) :

1. Harapan terhadap suatu subjek

2. Nilai dari objek itu

Semakin besar harapan seseorang terhadap suatu objek dan semakin tinggi nilai objek itu bagi orang tersebut, berarti akan semakin besar motivasinya, begitu juga sebaliknya jika harapan dan nilai tidak ada, maka tidak ada motivasi pada diri seseorang (Djalali, 2008).

Tujuan dari penelitian ini adalah untuk mengetahui hubungan antara motivasi berprestasi dengan hasil belajar mahasiswa jalur umum Program studi DIII Kebidanan STIKes Dharma Husada Bandung.

\section{METODE PENELITIAN}

Rancangan penelitian yang digunakan adalah survei analitik dengan pendekatan Cross sectional (Notoatmodjo, 2006). Sampel yang digunakan adalah seluruh mahasiswa jalur umum tingkat II Program Studi D3 Kebidanan STIKes Dharma Husada Bandung sebanyak 131 mahasiswa.

\section{HASIL PENELITIAN}

a. Motivasi Berprestasi

Hasil penelitian tentang motivasi berprestasi mahasiswa dapat dilihat pada tabel berikut :

Tabel 1.1 Distribusi frekuensi Motivasi Berprestasi mahasiswa jalur umum Program Studi D3 Kebidanan STIKes Dharma Husada Bandung

\begin{tabular}{lcc}
\hline Motivasi Berprestasi & Frekuensi & Persentase \\
\hline Tinggi & 93 & 71 \\
Sedang & 38 & 29 \\
Rendah & 0 & 0 \\
Sangat rendah & 0 & 0 \\
\hline Jumlah & $\mathbf{1 3 1}$ & $\mathbf{1 0 0 \%}$ \\
\hline
\end{tabular}


Berdasarkan tabel 1.1 dapat dilihat bahwa sebagian besar responden memiliki motivasi berprestasi tinggi yaitu sebanyak 93 $(71 \%)$ dan sebagian kecil memiliki motivasi berprestasi sedang yaitu sebanyak 38 (29\%). b. Hasil belajar

Hasil penelitian tentang hasil belajar mahasiswa dapat dilihat pada tabel berikut :

Tabel 1.2 Distribusi frekuensi Hasil Belajar mahasiswa jalur umum Program Studi D3 Kebidanan STIKes Dharma Husada Bandung

\begin{tabular}{lcc}
\hline Hasil Belajar & Frekuensi & Persentase \\
\hline Dengan pujian & 20 & 15,3 \\
Sangat memuaskan & 85 & 64,9 \\
Memuaskan & 25 & 19,1 \\
Kurang memuaskan & 1 & 0,8 \\
\hline Jumlah & $\mathbf{1 3 1}$ & $\mathbf{1 0 0} \%$ \\
\hline
\end{tabular}

Berdasarkan tabel 1.2 dapat dilihat bahwa sebagian besar responden memiliki hasil belajar sangat memuaskan yaitu sebanyak 85 $(64,9 \%)$ dan sebagain kecil responden memiliki hasil belajar kurang memuaskan yaitu sebanyak $1(0,8 \%)$.

c. Hubungan Motivasi Berprestasi dengan Hasil Belajar

Tabel 1.3 Hubungan Motivasi Berprestasi dengan Hasil Belajar mahasiswa jalur umum Program Studi D3 Kebidanan STIKes Dharma Husada Bandung

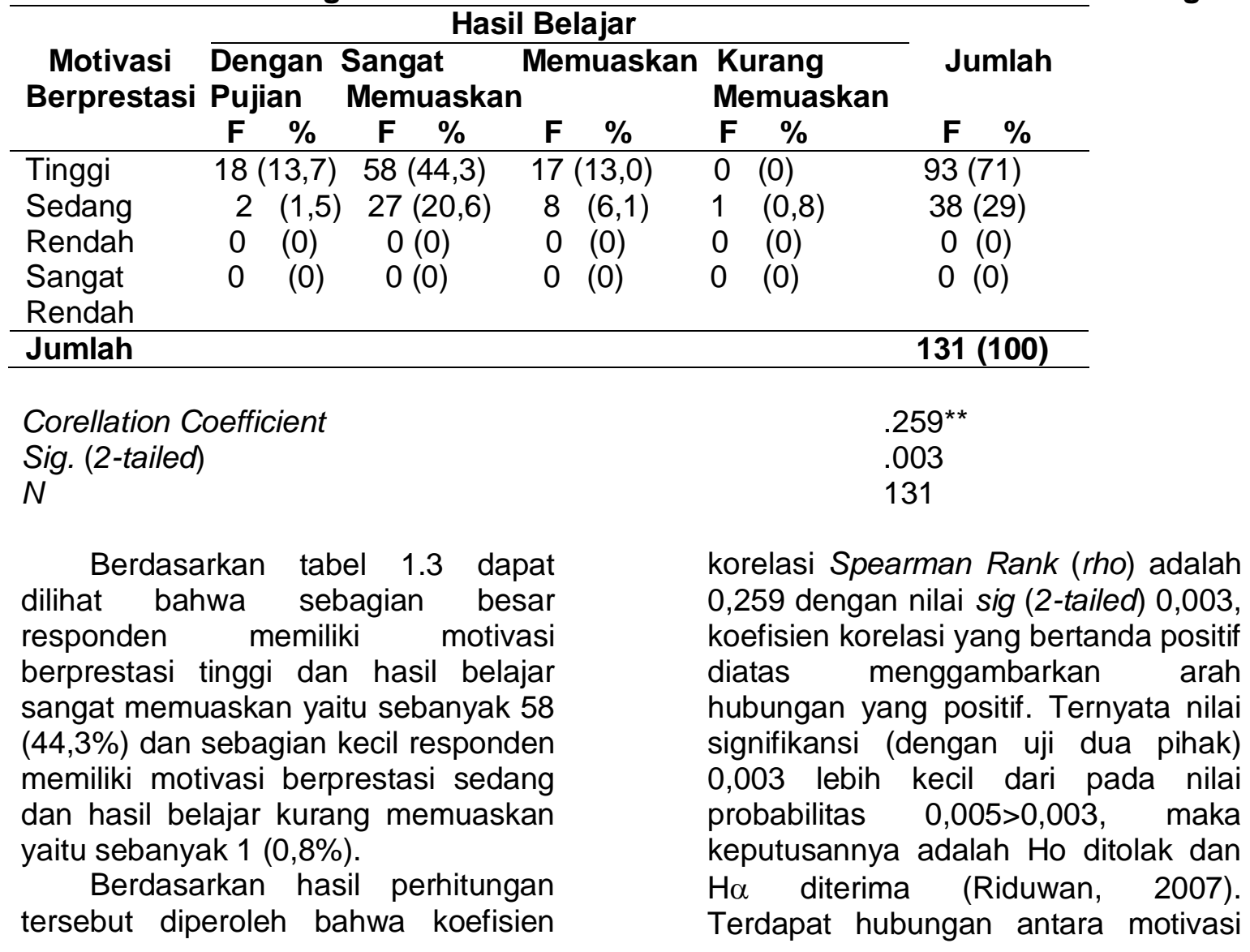

Hasil penelitian tentang
hubungan motivasi berprestasi dengan hasil belajar mahasiswa dapat dilihat pada tabel berikut : 
berprestasi dengan hasil belajar. Keeratan hubungan antara motivasi berprestasi secara statistik termasuk kedalam kategori rendah ( $r$ terletak antara $0,20-0,40)$.

\section{PEMBAHASAN}

a. Motivasi Berprestasi

Berdasarkan tabel 1.1 didapatkan bahwa motivasi berprestasi sebagian besar dengan kategori tinggi sebanyak 93 (71\%). Diindikasikan dengan dorongan kognitif, harga diri akademis (Academic self-esteem) dan komponen afiliasi. Berdasarkan hasil penelitian, komponen afiliasi (sebagian besar dengan kategori sedang) merupakan dimensi motivasi berprestasi yang paling rendah dibandingkan dengan dorongan kognitif dan harga diri akademis (Academic self-esteem) (sebagian besar dengan kategori tinggi). Sosialisasi mahasiswa STIKes Dharma Husada masih kurang, hal ini ditunjukan dengan mahasiswa tidak mengenal akrab mahasiswa lain yang berbeda kelas. Data ini menunjukan bahwa harapan mahasiswa untuk berhasil lebih besar (Motive of success/Ms) dari pada rasa takut akan kegagalan (Motive of avoid failure/Maf) (Singgih, Salim dan Sukadji, 2006) . Motivasi berprestasi tinggi disebabkan karena iklim belajar yang memberi semangat dan sikap optimisme bagi 'siswa' dalam belajar.

b. Hasil belajar

Berdasarkan tabel 1.2 didapatkan hasil bahwa hasil belajar mahasiswa sebagian besar dengan kategori sangat memuaskan yaitu sebanyak 85 (64,9\%). Hasil belajar sangat memuaskan ini disebabkan oleh motivasi berprestasi yang tinggi cenderung untuk mencapai sukses atau memilih sesuatu kegiatan yang berorientasi untuk tujuan sukses, dan jika mereka gagal, mereka akan berusaha lebih keras lagi sampai sukses (Djiwandono, 2008). Hasil belajar merupakan output dari suatu proses pembelajaran. Terdapat tiga faktor yang mempengaruhi hasil belajar, yaitu (Purwanto, 2006) :
1. Masukan mentah (Raw input), yaitu mahasiswa yang memiliki karakteristik tertentu baik fisiologis maupun psikologis (kapasitas IQ, bakat khusus, motivasi, minat, kematangan dan kesiapan, sikap, kebiasaan dan lain-lain)

2. Masukan instrumental (Intrumental input), yaitu sosial-faktor yang sengaja dirancang atau dimanipulasi, diantaranya dosen, metode, teknik, media, bahan sumber, administrasi atau manajemen, kurikulum, sarana dan prasarana.

3. Masukan lingkungan (Environmental input), yaitu lingkungan alam, sosial budaya, ekonomi dan lain-lain.

c. Hubungan Motivasi Berprestasi dan Hasil Belajar

Berdasarkan tabel 1.3 didapatkan hasil bahwa motivasi berprestasi dan hasil belajar sebagian besar dengan kategori tinggi dan sangat memuaskan yaitu sebanyak 58 (44,3\%). Adanya motivasi yang baik akan menunjukan hasil yang baik. Artinya, dengan adanya usaha yang tekun dan terutama didasari adanya motivasi, maka seseorang yang belajar akan dapat melahirkan hasil belajar yang baik (Sardiman, 2008).

Keyakinan akan adanya hubungan antara motivasi berprestasi dengan hasil belajar mahasiswa, berangkat dari asumsi bahwa motivasi merupakan salah satu faktor yang mempengaruhi hasil belajar. Asumsi ini terbukti bahwa berdasarkan penelitian yang telah dilakukan diperoleh hasil koefisien korelasi Spearman Rank (rho) sebesar 0,259 dengan nilai sig (2-tailed) 0,003 lebih kecil dari pada probabilitas 0,05 , maka dapat disimpulkan bahwa terdapat hubungan antara motivasi berprestasi dengan hasil belajar. Tingkat hubungan antara motivasi berprestasi dengan hasil belajar berdasarkan tabel interpretasi koefisien korelasi berada pada tingkat hubungan yang rendah $(r$ terletak antara 0,20-0,40). Hal ini sesuai dengan teori yang menyatakan bahwa motivasi seseorang merupakan 
salah satu faktor yang memengaruhi terhadap pencapaian hasil belajar yang baik.

Menurut Atkinson, di dalam diri setiap individu selalu terdapat pertentangan antara harapan akan sukses (Motive of success/Ms) dengan rasa takut akan mengalami kegagalan (Motive of avoid/Maf). Jika harapan akan sukses lebih besar dibandingkan dengan rasa takut akan mengalami kegagalan (Ms>Maf), maka orang akan termotivasi untuk mencapai tujuan (Singgih, Salim dan Sukadji, 2006).

Seseorang yang mempunyai motivasi berprestasi tinggi pada umumnya harapan akan suksesnya selalu mengalahkan rasa takut akan mengalami kegagalan dan akan merasa optimis dalam mengerjakan sesuatu yang dihadapinya, sehingga setiap saat termotivasi untuk mencapai tujuannya. Besar kecilnya pengaruh motivasi berprestasi dan hasil belajar tergantung pada intensitanya. Menurut Klausmeier perbedaan dalam itensitas motivasi berprestasi ditunjukan dengan barbagai tingkat hasil belajar yang dicapai oleh berbagai individu (Djalali, 2008).

Selain motivasi masih banyak lagi faktor lain yang mempengaruhi hasil belajar yang tidak penulis teliti. Faktor ini antara lain : Raw input (kapasitas $I Q$, bakat khusus, minat, kematangan dan kesiapan, sikap, kebiasaan), Instrumental input (dosen, metode, teknik, media, bahan, sumber, administrasi atau manajemen, kurikulum, sarana dan prasarana), Environmental input (lingkungan alam, sosial budaya, ekonomi).

\section{KESIMPULAN DAN SARAN}

a. Kesimpulan

Berdasarkan hasil penelitian dan pembahasan, maka diperoleh kesimpulan sebagai berikut :

1. Motivasi berprestasi mahasiswa jalur umum Program Studi D3 Kebidanan STIKes Dharma Husada Bandung, untuk dimensi komponen afiliasi dalam kategori sedang.

2. Hasil belajar mahasiswa jalur umum Program Studi D3 Kebidanan STIKes Dharma Husada Bandung, masih terdapat hasil belajar dengan kategori memuaskan dan kurang memuaskan.

3. Terdapat hubungan yang signifikan antara motivasi berprestasi dengan hasil belajar mahasiswa jalur umum Program Studi D3 Kebidanan STIKes Dharma Husada Bandung.

\section{b. Saran}

Diharapkan ada penelitian lebih lanjut untuk mengetahui faktor lain (selain motivasi berprestasi) yang memengaruhi hasil belajar dan faktor apa yang paling dominan memengaruhi hasil belajar.

\section{DAFTAR PUSTAKA}

Djalali. 2008. Psikologi pendidikan. Jakarta : Bumi Aksara.

Djiwandono, Sri Esti Wuryani. 2008. Psikologi pendidikan. Jakarta : Grasindo.

Kusumaningsih, Yuyun. 2009. FaktorFaktor Utama yang Berpengaruh terhadap Prestasi Belajar Mahasiswa Pascasarjana Penerima Beasiswa S2 dalam negeri BPK RI. Tesis pada Program Magister Universsitas Indonesia. 15.

Makmun, Abin Syamsuddin. 2006. Psikologi pendidikan perangkat sistem pengajaran modul. Bandung : Remaja Rosda Karya.

Notoatmodjo, Soekidjo. 2006. Metodologi penelitian kesehatan. Jakarta : Rineka Cipta.

Purwanto, Ngalim. 2006. Psikologi pendidikan. Bandung : Remaja Rosdakarya. 
Riduwan. 2007. Belajar mudah penelitian untuk guru, karyawan dan peneliti pemula. Bandung : Alfabeta.

Sardiman. 2008. Interaksi dan motivasi belajar mengajar. Jakarta : Raja Gravindo Persada.

Singgih EE, Salim, Sukadji S ed. 2006. Sukses belajar di perguruan tinggi. Yogyakarta : Panduan.
STIKes Dharma Husada. 2008. Company Profile. Bandung : STIKes Dharma Husada.

Sudjana, Nana. 2005. Penilaian Hasil Proses Belajar Mengajar. Bandung : PT Remaja Rosdakarya. 